\title{
СПЕЦИФІКА ВЖИВАННЯ АНГЛІЙСЬКОЇ МОВИ У ФРАЗЕОЛОГІЇ РАДІООБМІНУ
}

Підлубна О. М. Специфіка вживання англійської мови у фразеології радіообміну.

У статті розглянуто особливості професійної спілкування в авіаційній галузі та роль організації англомовної комунікації під час радіообміну. Визначено, що англійська мова стала невід'ємним чинником для забезпечення ефективності міжнародної взаємодії й безпеки під час авіаційних перевезень. Представлено основні причини непорозуміння між пілотом i диспетчером, (․ О. М. Підлубна, 2018. 


\section{СТРУКТУРА I СЕМАНТИКА МОВНИХ ОДИНИЦЬ}

розглянуто характеристики радіообміну цивільної авіації, які визначають мовні особливості кодування інформації в його межах, а саме: лаконічність, ясність, однозначність. Розглянуто лінгвістичні фактори, які впливають на ведення радіообміну: прогнозованість, переключення мовних кодів, паралінгвістичні фактори порушення радіообміну та лексична неоднозначність.

Ключові слова: загальна англійська мова, фразеологія, радіообмін, прогнозованість, переключення мовних кодів, паралінгвістичні фактори порушення радіообміну, лексична неоднозначність.

Подлубная О. Н. Специфика употребления $\quad$ английского языка $\quad$ в фразеологии радиообмена.

В статье рассматриваются особенности профессиональной общения в авиационной отрасли и роль организации англоязычной коммуникации во время радиообмена. Определяется, что английский язык стал неотъемлемым фактором для обеспечения эффективности международного взаимодействия и безопасности во время авиационных перевозок. Представлены основные причины непонимания между пилотом и диспетчером, рассмотрены характеристики радиообмена гражданской авиации, которые определяют языковые особенности кодирования информации в его пределах, а именно: лаконичность, ясность, однозначность. Исследуются лингвистические факторы, влияющие на ведение радиообмена: прогнозы, переключение языковых кодов, паралингвистические факторы нарушения радиообмена и лексическая неоднозначность.

Ключевые слова: общий английский язык, фразеология, радиообмен, прогнозы, переключение языковых кодов, паралингвистические факторы нарушения радиообмена, лексическая неоднозначность.

Pidlubna O. M. Specific Character of Using English in Phraseology of Radio Communication.

The article deals with the features of professional communication in the aviation industry and the role of the organization of English language communication during radiotelephony. English is the language for all pilots and air traffic controllers who wish to operate in any international aviation environment. The International Civil Aviation Organization, called ICAO, determines the English language requirements. It has been determined that English has become an integral factor in ensuring the effectiveness of international cooperation and security during air transport. The main factors of misunderstanding between the pilot and the air traffic controller are underlined, the radiotelephony characteristics of civil aviation are identified corresponding to the main principles of aviation communication of encoding information within its limits, namely: concision, clarity, non-ambiguity.

English has been chosen as the official language of flight in the United States and continues to be the recommended lingua franca for international use. In some cases, 
a lack of English proficiency in pilots or controllers has led to disastrous and even fatal catastrophes. While miscommunications between flight crews and air traffic control personnel may have been only one aspect of these incidents and accidents, the lack of ability for all parties involved to understand crucial directions via a common English may have been the most important contributing factor leading to these tragedies. Without agreed upon standards for English proficiency and common phraseology, the aviation industry continues to be at risk for future language-related accidents. Air traffic communications often deviate from standard phraseology in emergency situations towards a more conversational style. English proficiency beyond the basic understanding of aviation phraseology may be necessary. In addition, a cultural awareness of the variety of English spoken in countries encountered during flight may help avoid misunderstandings and miscommunications.

Miscommunications may broadly be applied to a range of verbal communications problems ranging from misunderstandings, such as those due to ambiguity, cultural differences, language structure, and so on, to more technical problems. Studies indicate that miscommunication is a pervasive problem in air traffic control and, has been a causal factor in numerous fatal accidents. According to the researches types of miscommunication can be grouped as follows: expectations, code switching and L1 interference problems, paralinguistic factors and lexical ambiguity.

Key words: plain language, phraseology, radiotelephony, expectations, code switching and L1 interference problems, paralinguistic factors and lexical ambiguity.

Англійська мова стала обов'язковою й необхідною в умовах розвитку й постійних змін у сучасному суспільстві, науці, техніці та технології. Задля підвищення безпеки польотів активізується увага до професійного спілкування між пілотом та авіадиспетчером. Міжнародною організацією цивільної авіації (IКАО) у 1947 р. було встановлено, що міжнародна радіотелефонна комунікація між пілотами й диспетчерами управління повітряним рухом має відбуватися англійською мовою [2]. Важливість володіння пілотом та диспетчером уміннями й навичками професійного спілкування пояснюється високою ціною помилки, оскільки від діалогу залежить не тільки успіх людської діяльності, а й життя пасажирів.

Для підвищення безпеки польотів посилюється інтерес до професійного спілкування між пілотом та авіадиспетчером. Головними завданнями професійного спілкування $є$ ясність, точність і правильність. Специфічність, точність і прямота $\epsilon$ 
якісними характеристиками професійного спілкування, які спрямовані на краще взаєморозуміння між пілотом і диспетчером. Основне в радіообміні - помірний обсяг інформації, чітка пауза між словами та фразами. Відповідно, авіаційна англійська мова становить особливий інтерес для мовознавців, оскільки посідає особливе місце в англійській мові загалом, вирізняється фонетичними, лексичними та граматичними особливостями.

Питаннями структури авіаційної англійської мови радіотелефонії займалися І. Асмукович, Н. Дупікова, А. Кириченко, Т. Мальковська. Низку робіт присвячено вивченню проблеми англійської мови як чинника безпеки польотів (Д. Макмілан, Н. Мод, Є. Кміта, С. Кушинг). Проте специфіка вживання англійського мови в радіообміні льотного складу ще не була предметом спеціального вивчення.

Мета статті полягає в тому, щоб розкрити специфіку вживання англійської мови у фразеології під час радіообміну.

Англійська мова вже давно стала міжнародною мовою спілкування в авіації, при цьому з огляду на те, що сам радіообмін - це акт комунікації між пілотом повітряного судна та диспетчером управління повітряним рухом, виникає необхідність у навчанні майбутніх авіафахівців комунікації мовою, що не є для них рідною [7]. Важливо відзначити: мова відіграє важливу роль у спілкуванні пілота й диспетчера, оскільки вони не спілкуються особисто, а через радіотелефонію. Основним фактором у процесі спілкування між пілотом та диспетчером стала фразеологія радіообміну, що скерована на ефективне спілкування й уможливлює чи то зменшення, чи то недопущення помилок і непорозумінь. Для уникнення нещасних випадків та інцидентів, які виникали внаслідок використання неоднозначної або нестандартної фразеології, було окреслено міжнародні стандарти фразеології в авіаційному Документі ICAO 9432 «Керівництво 3 ведення радіотелефонного зв'язку» [2].

Для гарантування безпеки польоту льотний екіпаж i 
диспетчери повинні дотримуватися встановлених процедур, аби кожна репліка повідомлення була зрозумілою. Радіообмін містить мовні кліше загальної англійської мови, інколи адаптовану регіональну або місцеву фразеологію, використовувану задля ефективного спілкування в нестандартній ситуації або в контексті позапрофесійного середовища.

Під час польоту важливо забезпечити ефективний, чіткий, надійний зв'язок між повітряним судном і диспетчером. Процес радіообміну між пілотом і диспетчером має суворий регламент, де пілот повідомляє про своє місцезнаходження, повітряну обстановку та намір, а диспетчер має адекватно зреагувати на запит, дати чіткі й однозначні вказівки. Процес спілкування має бути успішним навіть у найскладніших умовах [1].

Свого часу науковець Г. Емері зауважував: ядром мови авіаційного зв'язку $є$ фразеологія радіообміну, що передбачає набір фраз, використовуваних у стандартних чи нестандартних ситуаціях [6, с. 46]. Максимально зрозумілими, лаконічними, однозначними мовними зворотами послуговуються у спілкуванні тільки для передачі інформації у стандартних ситуаціях, однак їх недостатньо в нестандартних. Фразеологія, як відомо, являє собою специфічний різновид мови, зокрема й англійської, характеризується конкретним діапазоном лексичних засобів. Американський учений $\mathrm{X}$. Бастуркмен запевняє, що фразеологія покриває лише рутинні та стандартні ситуації. Лексика фразеології однотипна й обмежена у вживані [3].

Ядром авіаційного спілкування, безумовно, $\epsilon$ радіотелефонна фразеологія. У разі недостатньої кількості тих чи тих мовних зворотів для передачі інформації пілот і диспетчер послуговуються загальною англійською мовою, яка уможливлює спілкування в нестандартних чи надзвичайних ситуаціях під час польоту. Звідси, відповідно, задля успішного радіообміну пілоти й диспетчери зобов'язані володіти фразеологією, мати потрібні навички застосування загальної розмовної мови і в іiі межах 
використовувати різноманітні терміни, властиві авіаційній галузі.

Загальною англійською мовою послуговуються в разі, якщо відповідної фразеології недостатньо для ведення радіообміну. Згідно з позицією Д. Мороу, коли спілкування є проблематичним, загальна англійська мова стає засобом для порозуміння співрозмовників, дає змогу впевнитися, що вони все зрозуміли або їх зрозуміли правильно [9]. Лінгвіст зауважував: «загальна англійська мова має більш складний синтаксис, неточну й нестандартну термінологію» [9, с. 253-254]. Тому використання загальної англійської мови під час ведення радіообміну може спричинити непорозуміння. Зіставлення загальної англійської мови і фразеології засвідчує, що перша є менш обмеженою, ніж друга. Мова радіообміну має незначні відмінності у вимові й інтонації, значні розбіжності у граматичних структурах, різний тип мовлення. Вона вирізняється чіткою структурованістю, насиченістю числівниками, термінологією та псевдотехнічною лексикою [2].

C. Макшейн та М. Фон Гліноу наголошували, що «спілкування належить до процесу, у якому інформація повідомлення зрозуміла для двох або більше співрозмовників» [8, с. 324]. Успішне спілкування в радіообміні грунтоване на чітких та лаконічних повідомленнях пілота та диспетчера, на взаєморозумінні двох фахівців, коли повідомлення відправника зрозуміле отримувачеві. Розглянемо лінгвістичні фактори, які впливають на ведення радіообміну: прогнозованість (expectations), переключення мовних кодів (code switching), паралінгвальні фактори порушення радіообміну (paralinguistic factors) та лексична неоднозначність (lexical ambiguity) [4; 7].

У радіообміні більшість ситуацій пов'язані одна 3 одною і мають рутинний характер. Основне завдання пілота полягає в тому, щоб чи то передати повідомлення, чи то отримати підтвердження. С. Кушинг констатував: значна кількість ситуацій непорозуміння належить до фактору прогнозування (очікування), тобто слухач сприймає не те, що він чує, а те, що він очікує почути 
в отриманому повідомленні [5]. Відхилення від стандартів зазвичай не помічає пілот, а повторення сприймається як отримане повідомлення. Пілоти інтерпретують ситуації та повідомлення відповідно до їхньої обізнаності й досвіду.

Так, скажімо, інцидент, який стався внаслідок плутанини інформації, пов'язаний із помилкою ведення радіообміну. 4 серпня 2011 року екіпаж літака «Luxair Embraer 145» здійснював регулярний пасажирський рейс до Мадриду. Пілот неправильно прочитав повідомлення диспетчера про зниження висоти до 10000 футів, помилково підтвердив висоту 5000 футів, тобто диспетчер допустився помилки [5]. Вона спричинена низкою чинників, як-от: недотримання стандартних процедур для ведення радіотелефонного зв'язку, неправильна видача дозволів при управлінні повітряним рухом, некоректні дії командира повітряного судна, неуважність диспетчера повітряного руху, що не помітив розбіжність у повідомленні.

Оскільки англійська мова здебільшого не $є$ рідною для учасників радіообміну, використовуються й інші мови, які сприяють переключенню мовних кодів, що стосується передовсім тих осіб, для яких англійська мова не є рідною. Однак не тільки, бо спостерігається й серед носіїв англійської мови [10].

Переключення мовних кодів у радіообміні подекуди спричинене використанням авіаційного жаргону, що його застосовують у різних сферах діяльності або спеціальних ситуаціях і який так само є засобом успішного спілкування, робить професійне спілкування більш ефективним. Щоправда, і в цьому разі можуть виникнути проблеми непорозуміння, адже не всі учасники комунікації можуть правильно ним послуговуватися й потрактовувати [7, с. 110].

Слова в загальній англійській мові та в авіаційному жаргоні мають різне значення. С. Кушинг ілюструє відповідні відмінності на прикладі слова hold. На авіаційному жаргоні hold означає “stop what you are doing”, але у загальній англійській мові має значення 
«продовжити на тому самому рівні» [5, с. 11].

Паралінгвальні елементи процесу спілкування беруть активну участь у творенні змісту інформації, що передається, адже інформація може передаватися одразу кількома каналами: словесним, інтонаційним, ситуативним. Успішність / неуспішність здійснення радіообміну значною мірою залежить від паралінгвальних чинників. Оскільки радіообмін здійснюється в рамках живого мовлення, то його не можна розглядати ізольовано від емоцій та обставин, які транслюються під час спілкування, індивідуальних особливостей мовця й ситуації спілкування. У процесі радіообміну важливими стають якість голосу, тембр, гучність, висота, інтонація, пауза, наголос, швидкість передачі повідомлення й інші аналогічні дії співрозмовників. Такі чинники можуть змінювати форму та значення повідомлення, відіграють важливу роль в ефективному спілкування, мають потужний вплив на одержувача. Так, скажімо, надмірна кількість пауз у радіообміні може стати перешкодою для продуктивного спілкування. Особливо під час нестандартних або стресових ситуацій, коли в пілота змінюється темп голосу, тон, інтонація, що зазвичай i спричиняє помилки під час передачі повідомлення.

Ще однією важливою проблемою може стати лексична неясність. Наявні ситуації, коли через сторонній шум співбесідники плутають слова, що звучать однаково, але мають різне написання $\mathrm{i}$ значення (фонетичні омоніми або омофони). Наприклад, to і two; right i write; missed i mist. Інцидент, який стався внаслідок плутанини i міг спричинити навіть зіткнення, пов'язаний iз фонологічною схожістю to та $t w o$, коли пілот неправильно зрозумів наказ "climb two five zero" як "climb to five zero". Абсолютні омоніми - слова, що звучать і пишуться однаково: refuse (disagree) / refuse (rubbish); close (shut) / close (near). Лексичні омоніми однакові за граматичними характеристиками, але різні за значенням. Однакова звукова та графічна форма і граматичні ознаки дають змогу вважати їх омонімами, але значеннєва різниця зараховує ці 
омоніми до розряду лексичних [5]: go ahead (urge speaking) - go ahead (forward motion); stand by (wait) - stand by (standing).

Отже, лексика англійської мови у фразеології радіообміну має свою специфіку. Фразеологія $є$ мовленням авіаційних спеціалістів, мета якого полягає у вербальному обміні професійною інформацією під час польоту за допомогою радіотелефонного зв'язку засобами англійської мови. Вона має низку лінгвістичних особливостей, що вирізняють іiі 3-поміж інших професійних мов і забезпечують чіткість, лаконічність та однозначність. Крім того, для ведення радіообміну пілоти й диспетчери повинні володіти не лише фразеологією, а й мати необхідні навички застосування загальної англійської мови, у іiі межах використовувати різноманітні терміни, властиві авіаційній галузі.

\section{Література}

1. Мальковская Т. А. Англо-русские соответствия в языковой структуре радиообмена в режиме общения пилот-авиадиспетчер : дисс. ... канд. филол. наук : 10.02.20 / Т. А. Мальковская. - Пятигорск, 2004. - 163 с.

2. Руководство по радиотелефонной связи : Дос 9432 AN / 925. - [4-е изд.]. Монреаль : Международная организация гражданской авиации, 2007.

3. Basturkmen H. Ideas and options in English for specific purpose / H. Basturkmen. - London : Lawrence Erlbaum associated publishers, 2006. - 199 p.

4. Carver D. Some prepositions about ESP / D. Carver // The ESP Journal. - 1983. - P. 131-137.

5. Cushing S. Fatal words: communication clashes and Aircraft Crashes. - Chicago, IL, USA : The University of Chicago Press, $2007-176 \mathrm{p}$.

6. Emery H. Plain English / H. Emery // English Teaching Professional. - 2008. № 56. - P. 46-47.

7. Mackay R. English for specific purpose: a case study approach / R. Mackay, A. Mountford. - London : Longman, 1978. $-240 \mathrm{p}$.

8. McShane S. L. Organizational behavior / S. L. McShane, M. A. Von Glinow. ( $3^{\text {rd }}$ ed. $)$ - New York : McGraw-Hill/Irwin, 2005. -688 p.

9. Morrow D. Nonroutine transactions in controller-pilot communication D. Morrow, M. Rodvold, L. Alfred // Discourse Process. - 1994. - № 2. - P. 235-258.

10. Robinson P. ESP Today : A practioner's guide / P. Robinson // New York : Prentice Hall. International Ltd, 1991. - 224 p.

Стаття надійшла до редакиії 01.03.2018 p.

() О. М. Підлубна, 2018. 